\title{
PENGARUH GAYA KEPEMIMPINAN, MOTIVASI KERJA DAN BUDAYA ORGANISASI TERHADAP KINERJA KARYAWAN PADA PT. BANK BNI SYARIAH PALU
}

\author{
Hariyanto R Djatola Djampagau \\ Sekolah Tinggi Ilmu Ekonomi (STIE) Panca Bhakti Palu \\ hilalnur2804@gmail.com
}

\begin{abstract}
This research aims to (1) know and analyse The effect of leadership style, work motivation and organizational culture on staff performance of PT. Bank BNI Syariah Palu; (2) know and analyse the effect of leadership style on staff performance of PT. Bank BNI Syariah Palu; (3) know and analyse the effect of work motivation on staff performance PT. Bank BNI Syariah Palu; (4) know and analyse the effect of organizational culture on staff performance of PT. Bank BNI Syariah Palu. Population in this research is 45 staff, and all of them become sample. Data in this research is analyzed by using multiple linear regression. The result shows that (1) leadership style, work motivation and organizational culture simultaneously perform positive and significant effect on staff performance of PT. Bank BNI Syariah Palu; (2) leadership style performs positive and significant effect on staff performance of PT. Bank BNI Syariah Palu; (3) work motivation performs positive and significant effect on staff performance of PT. Bank BNI Syariah Palu; and (4) organizational culture performs positive and significant effect on staff performance of PT. Bank BNI Syariah Palu
\end{abstract}

Key Words: leadership style, work motivation, organizational culture, staff performance

\begin{abstract}
Abstrak
Tujuan penelitian ini adalah untuk menguji pengaruh gaya kepemimpinan, motivasi kerja dan budaya organisasi terhadap kinerja karyawan PT. Bank BNI Syariah Palu. Penelitian ini dilakukan di PT. Bank BNI Syariah Palu, responden yang digunakan sebanyak 44 karyawan, menggunakan Analisis Regresi Linier Berganda. Hasil penelitian menunjukkan gaya kepemimpinan, motivasi kerja dan budaya organisasi mempunyai pengaruh positif dan signifikan terhadap kinerja karyawan PT. Bank BNI Syariah Palu. Pengaruh dari gaya kepemimpinan terhadap kinerja karyawan PT. Bank BNI Syariah Palu adalah signifikan dan positif; pengaruh dari motivasi kerja terhadap kinerja karyawan PT. Bank BNI Syariah Palu adalah signifikan dan positif; dan budaya organisasi terhadap kinerja karyawan PT. Bank BNI Syariah Palu adalah signifikan dan positif.
\end{abstract}

Kata Kunci: gaya kepemimpinan, motivasi kerja, budaya organisasi, dan kinerja pegawai

\section{PENDAHULUAN}

Perubahan lingkungan organisasi yang semakin kompleks dan kompetitif, menuntut setiap organisasi dan perusahaan untuk bersikap lebih responsif agar sanggup bertahan dan terus berkembang. Untuk mendukung perubahan organisasi tersebut, maka diperlukan adanya perubahan individu. Proses menyelaraskan perubahan organisasi dengan perubahan 
individu ini tidaklah mudah. Pemimpin sebagai panutan dalam organisasi, sehingga perubahan harus dimulai dari tingkat yang paling atas yaitu pemimpin itu sendiri. Maka dari itu, organisasi memerlukan pemimpin reformis yang mampu menjadi motor penggerak yang mendorong perubahan organisasi.

Sampai saat ini, kepemimpinan masih menjadi topik yang menarik untuk dikaji dan diteleti, karena paling sering diamati namun merupakan fenomena yang sedikit dipahami. Fenomena gaya kepemimpinan di Indonesia menjadi sebuah masalah menarik dan berpengaruh besar dalam kehidupan politik dan bernegara. Dalam dunia bisnis, gaya kepemimpinan berpengaruh kuat terhadap jalannya organisasi dan kelangsungan hidup organisasi. Peran kepemimpinan sangat strategis dan penting dalam sebuah organisasi sebagai salah satu penentu keberhasilan dalam pencapaian misi, visi dan tujuan suatu organisasi. Maka dari itu, tantangan dalam mengembangkan strategi organisasi yang jelas terutama terletak pada organisasi di satu sisi dan tergantung pada kepemimpinan (Porter, 1996 : dalam Sunarsih, 2001).

Begitu pentingnya peran kepemimpinan dalam sebuah organisasi menjadi fokus yang menarik perhatian para peneliti bidang perilaku keorganisasian. Bass (1990) menyatakan bahwa kualitas dari pemimpin sering kali dianggap sebagai faktor terpenting yang menentukan keberhasilan atau kegagalan organisasi. Schein (1992), Nahavandi \& Malekzadeh (1993) serta Kouzes \& Posner (1987) juga menyatakan bahwa pimpinan mempunyai pengaruh besar terhadap keberhasilan organisasi. Porter (1996) dalam Sunarsih (2001). Green Berg dan Baron (2000 : 444) dalam Sunarsih (2001) menyatakan bahwa kepemimpinan merupakan suatu unsur kunci dalam keefektifan organisasi.

Seiring dengan perkembangan teknologi informasi yang semakin cepat dan perekonomian Indonesia yang kurang stabil, hal ini bisa saja menjadi sumber, kendala organisasi namun bisa juga menjadi sumber keuntungan organisasi.

Kepemimpinan yang efektif bisa membantu organisasi untuk bisa bertahan dalam situasi ketidakpastian di masa datang (Katz and Khan 1978; Koh et al. 1995; Mowday et al. 1982). Seorang pemimpin yang efektif harus tanggap terhadap perubahan, mampu menganalisis kekuatan dan kelemahan sumber daya manusianya sehingga mampu memaksimalkan kinerja organisasi dan memecahkan masalah dengan tepat. Pemimpin yang efektif sanggup mempengaruhi para pengikutnya untuk mempunyai optimisme yang lebih besar, rasa percaya diri, serta komitmen kepada tujuan dan misi organisasi (Yukl, 1994). Hal ini membawa konsekuensi bahwa setiap pemimpin berkewajiban untuk memberikan perhatian sungguh-sungguh dalam membina, menggerakkan dan mengarahkan seluruh potensi karyawan di lingkungannya agar dapat mewujudkan stabilitas organisasi dan peningkatan produktivitas yang berorientasi pada tujuan organisasi.

Model kepemimpinan modern seperti kepemimpinan transformasional memainkan peranan penting bagi organisasi. Bass (1985) dalam Sunarsih (2001) mendefinisikan bahwa kepemimpinan transformasional sebagai pemimpin yang mempunyai kekuatan untuk mempengaruhi bawahan dengan cara-cara tertentu. Bawahan merasa percaya, kagum, loyal 
dan hormat terhadap atasannya sehingga bawahan termotivasi untuk berbuat lebih banyak dari pada apa yang biasa dilakukan dan diharapkannya. Jung dan Avolio (1999) dalam Sunarsih (2001) juga menyatakan bahwa kepemimpinan transformasional meliputi pengembangan hubungan yang lebih dekat antara pemimpin dengan pengikutnya, bukan hanya sekedar sebuah perjanjian tetapi lebih didasarkan kepada kepercayaan dan komitmen. Kepemimpinan transformasional pada prinsipnya memotivasi bawahan untuk berbuat lebih baik dari apa yang biasa dilakukan, dengan kata lain dapat meningkatkan kepercayaan atau keyakinan diri bawahan yang akan berpengaruh terhadap peningkatan kinerja.

Kepemimpinan adalah kemampuan untuk mempengaruhi orang lain untuk mencapai tujuan dengan antusias (David, Keith, 1985). Seorang pemimpin harus mampu mempengaruhi para bawahannya untuk bertindak sesuai dengan visi, misi dan tujuan perusahaan. Pemimpin harus mampu memberikan wawasan, membangkitkan kebanggaan, serta menumbuhkan sikap hormat dan kepercayaan dari bawahannya. Pemimpin yang efektif adalah pemimpin yang mengakui kekuatan-kekuatan penting yang terkandung dalam individu. Setiap individu memiliki kebutuhan dan keinginan yang berbeda-beda. Setiap individu memiliki tingkat keahlian yang berbeda-beda pula. Pemimpin harus fleksibel dalam pemahaman segala potensi yang dimiliki oleh individu dan berbagai permasalahan yang dihadapai individu tersebut. Dengan melakukan pendekatan tersebut, pemimpin dapat menerapkan segala peraturan dan kebijakan organisasi serta melimpahkan tugas dan tanggung jawab dengan tepat. Hal ini sejalan dengan usaha untuk menumbuhkan komitmen organisasi dari diri karyawan. Sehingga pemimpin nantinya dapat meningkatkan kepuasan karyawan terhadap pekerjaannya serta dapat meningkatkan kinerja karyawan dengan lebih efektif.

Teori Path-Goal (Evans, 1970; House, 1971; House\&Mitchell, 1974 dalam Yulk, 1989) mengatakan bahwa pemimpin mendorong kinerja yang lebih tinggi dengan cara memberikan kegiatan-kegiatan yang mepengaruhi bawahannya agar percaya bahwa hasil yang berharga bisa dicapai dengan usaha yang serius. Kepemimpinan yang berlaku secara universal menghasilkan tingkat kinerja dan kepuasan bawahan yang tinggi.

Selain dari hal gaya kepemimpinan yang ditujukan seorang pemimpin untuk memberikan arahan kepada bawahan, hal penting lain yang harus dipahami oleh seorang pemimpin bahwa mengatur karyawan adalah hal yang sulit dan kompleks, karena mereka mempunyai pikiran. Perasaan, status keinginan dan latar belakang yang heterogen yang dibawa ke dalam organisasi. Karyawan tidak dapat diatur dan dikuasai sepenuhnya seperti mengatur mesin, modal atau gedung, karyawan merupakan aset yang sangat berharga yang dimiliki oleh perusahaan. Tujuan tidak mungkin terwujud tanpa peran aktif karyawan meskipun alat-alat yang dimiliki perusahaan begitu canggihnya. Alat-alat canggih yang dimiliki perusahaan tidak ada manfaatnya bagi perusahaan, jika peran aktif karyawan tidak diikutsertakan. Sehingga untuk bisa memadukan antara kepentingan perusahaan dan kebutuhan karyawan seorang pemimpin harus mengintegrasikan kedua hal tersebut, salah satunya dengan pemberi motivasi. Dengan motivasi ini pemimpin dapat mendorong atau 
menggerakkan potensi bawahan, agar mau bekerja sama secara produktif berhasil dan mewujudkan tujuan yang telah ditentukan, perusahaan bukan saja mengharapkan karyawan mampu, cakap dan terampil, tetapi yang terpenting mereka mau bekerja giat dan berkeinginan untuk mencapai hasil kerja yang maksimal. Kemampuan dan kecakapan karyawan tidak ada artinya bagi perusahaan jika mereka tidak mau bekerja dengan giat. Kecanggihan peralatan yang didukung Sumber Daya Manusia yang terampil dan berkualitas akan dapat memberikan manfaat yang besar bagi perusahaan sesuai dengan tuntutan perkembangan keadaan. Gaya kepemimpinan seorang pemimpin dan motivasi yang diberikan oleh pemimpin kepada bawahannya sangat berpengaruh terhadap kinerja bawahan dalam hal ini adalah karyawan. Kinerja yang baik dari bawahan dapat diperoleh dengan gaya kepemimpinan dan motivasi pemimpin yang baik pula. Kinerja merupakan cara yang diperoleh dari kedua hal tersebut dalam menyelesaikan tugas atau pekerjaan seseorang dan suatu hal penting dalam upaya perusahaan untuk mencapai tujuan perusahaan.

Budaya organisasi salah satu faktor yang mempengaruhi kinerja karyawan dalam organisasi. Secara teoritis, budaya organisasi tidak lepas dari strategi organisasi, termasuk visi dan misi organisasi itu sendiri (Moeljono \& Sudjatmiko, 2007) dan merupakan salah satu faktor penting dalam implementasi strategi. Budaya ini dapat berasal dari seorang pemimpin yang kemudian dianut dan diikuti oleh pengikutnya. Budaya ini berkaitan erat dengan nilainilai dan norma yang pegang dan berlaku oleh karyawan dalam melakukan pekerjaanya. Budaya yang kuat merupakan landasan kinerja suatu organisasi.

Jika terdapat budaya yang tidak kondusif dalam suatu organisasi maka mungkin dapat mempengaruhi karyawan dalam melakukan aktivitasnya dan secara langsung mempengaruhi kinerja masing-masing karyawan.

Kinerja pegawai tidak lepas dari peran pemimpinnya. menurut Bass (1990), peran kepemimpinan atasan dalam memberikan kontribusi pada karyawan untuk pencapaian kinerja yang optimal dilakukan melalui lima cara, yaitu : (1) Pemimpin mengklarifikasi apa yang diharapkan dari karyawannya, secara khusus tujuan dan sasaran dari kinerja mereka, (2) Pemimpin menjelaskan bagaimana memenuhi harapan tersebut, (3) Pemimpin mengemukakan kriteria dalam melakukan evaluasi dari kinerja secara efektif, (4) Pemimpin memberikan umpan balik ketika karyawan telah mencapai sasaran, dan (5) Pemimpin mengalokasikan imbalan berdasarkan hasil yang telah mereka capai.

PT. Bank BNI Syariah adalah perusahaan perbankan yang berlandaskan hukum secara syariah, berlokasi pusat di Jakarta. Sebagai Perusahaan Perbankan PT. Bank BNI Syariah menyadari sepenuhnya bahwa komitmen dan profesionalisme pelayanan sangatlah diperlukan. Produk-produk yang di tawarkan PT. Bank BNI Syariah sebagian besar adalah berupa produk tabungan, namun ada produk championnya yaitu Griya IB Hasanah yang memberikan kredit griya kepada nasabah dengan rate paling rendah.

Dengan semakin majunya era globalisasi ini, maka perkembangan perbankan pun semakin meningkat. PT. Bank BNI Syariah mempunyai semboyan "Amanah dan Jamaah" semboyan inilah yang ingin diterapkan di seluruh jajaran perusahaan. Untuk mendapatkan 
kepercayaan nasabah secara terus-menerus, maka dari PT. Bank BNI Syariah selalu berupaya memberikan bonus yang menarik di setiap produknya, menjaga nasabah prima agar tetap loyal dengan perusahaan serta selalu mengedepankan pelayanan yang baik bagi nasabah. PT.Bank BNI Syariah memiliki visi menjadi bank syariah pilihan masyarakat yang unggul dalam layanan dan kinerja. Untuk itu PT. Bank BNI Syariah selalu berusaha memberikan pelayanan dan kinerja terbaik bagi nasabah maupun calon nasabah.

Obyek pada penelitian ini adalah kantor cabang PT. Bank BNI Syariah Palu. Lingkup dari kantor area ini untuk saat ini hanya seputar kota Palu, karena untuk cabang Palu yang baru berdiri sekitar 1 tahun 5 bulan jadi belum mempunyai kantor Cabang di daerah lain. Namun PT. Bank BNI Syariah telah mempunyai rencana untuk membuka kantor cabang pembantu di beberapa daerah, misalnya di kawasan area Universitas Al-khairaat, Luwuk dan Toli-Toli. Dalam kantor ini terbagi atas beberapa unit yaitu bisnis, operasional, layananan, umum dan administrasi. Untuk para Direct Sales masuk dalam tanggung jawab umum walaupun mereka bekerja dan nilai dari supervisor di unit mereka bertugas. Para Direct Sales, Assisten Supervisor dan Supervisor (terutama bagian Dana) inilah yang terjun langsung dan bertatap muka dengan nasabah, merekalah yang menjadi ujung tombak dari perusahaan.

Akibat dari PT. Bank BNI Syariah yang baru berpisah dari induknya yaitu, PT. Bank BNI sekitar 3 tahun yang lalu pada tanggal 16 Juli 2010, berdampak pada pembenahan struktrur organisasi yang sering berubah terutama pada posisi pemimpin terutama di Bank BNI Syariah Palu yang membuat kinerja dari para karyawan tidak efektif dalam mencapai target yang telah di tetapkan dari kantor pusat. Hal ini disebabkan karena setiap bergantinya pimpinan, jelas gaya kepemimpinannya pun berbeda mulai dari cara memimpin dan pola berpikirnya yang secara tidak langsung kita sebagai bawahan harus segera menyesuaikan dengan perubahan tersebut. Namun pada intinya, mereka mempunyai tujuan yang sama yaitu untuk memajukan perusahaan dalam mencapai target-target yang telah ditetapkan, agar mencapai laba yang maksimal sehingga dapat mensejahterahkan para karyawan yang telah bekerja keras dalam mencapai target perusahaan.

Fenomena yang terjadi di PT. Bank BNI Syariah Palu akibat sering berubahnya struktur organisasi terutama perubahan pimpinan sangat berpengaruh terhadap kinerja karyawan. Yang tadinya mempunyai pimpinan dengan gaya militeristis yang sering memberi perintah kepada bawahan dan tanggung jawab penuh berada di tangannya, tiba-tiba berubah ke pimpinan yang sangat demokratis dimana dalam hal ini jabatan seorang pimpinan hanya melekat sebagai nama saja bukan kuasa untuk menjalankan perusahaan.

Segi motivasi kerja dari diri karyawan sendiri, tidak ada perubahan karena dengan bergantinya pimpinan target-target yang di tetapkan masih sama dan tidak ada perubahan sehingga kami sebagai bawahan tetap menjalankan strategi yang telah kami gunakan sejak awal, karena pimpinan yang saat ini memimpin pun tidak memotivasi kami sebagai karyawan untuk selalu semangat dan fokus dalam mencapai target-target yang di tetapkan. Namun hal yang paling nampak dari adanya pergantian pimpinan ini adalah dari segi budaya organisasi "Amanah dan Jamaah" yang selama ini di pegang teguh bahkan berusaha untuk selalu 
diperbaiki setiap harinya makin hari makin terasa kerenggangannya terutama dalam hal jamaah ini di dalam perusahaan. Yang tadinya kami sangat solid dan saling mendukung antara satu unit dengan unit kerja lainnya dalam melakukan pekerjaan, namun saat ini yang terjadi rasa solid itu sudah tidak ada lagi.

Gaya kepemimpinan yang efektif dalam mengelola sumber daya manusia dalam suatu unit kerja akan berpengaruh pada perilaku kerja yang diindikasikan dengan peningkatan kepuasan kerja individu dan kinerja unit itu sendiri, yang pada akhirnya akan mempengaruhi kinerja perusahaan secara keseluruhan. Seorang pemimpin juga harus mampu menciptakan komitmen organisasi pada karyawannya dengan menanamkan visi, misi, dan tujuan dengan baik untuk membangun loyalitas dan kepercayaan dari karyawannya.

Dengan demikian, berdasarkan uraian di atas maka yang menjadi rumusan masalah pada penelitian ini adalah:

1. Apakah gaya kepemimpinan, motivasi kerja dan budaya organisasi secara simultan mempunyai pengaruh yang positif dan signifikan terhadap kinerja karyawan?

2. Apakah gaya kepemimpinan mempunyai pengaruh yang positif dan signifikan terhadap kinerja karyawan?

3. Apakah motivasi kerja mempunyai pengaruh yang positif dan signifikan terhadap kinerja karyawan?

4. Apakah budaya organisasi mempunyai pengaruh yang positif dan signifikan terhadap kinerja karyawan?

\section{METODE}

Penelitian ini digunakan metode penelitian yang bersifat deskriptif verifikatif yaitu penelitian yang menggunakan penyajian jawaban dari hasil pemikiran yang kebenarannya bersifat sementara (hipotesis). Demikian pula data mengenai hubungan antara variabel dalam penelitian ini.

Penelitian ini berlokasi di PT. Bank BNI Syariah Palu dan waktu penelitiannya adalah bulan Agustus 2015. Lokasi penelitian dipilih secara sengaja (purposive), dengan pertimbangan selain tempat ini adalah tempat bekerja saya, penelitian tersebut juga belum pernah dilakukan oleh peneliti lain di PT. Bank BNI Syariah Palu. Berdasarkan daPopulasi dalam penelitian ini adalah 45 karyawan yang terdiri dari 26 pegawai organik, 4 pegawai outsourcing dan 13 pegawai dasar.

Tabel 1. Jumlah Karyawan PT. Bank BNI Syariah Palu

\begin{tabular}{|c|c|c|}
\hline No. & \multicolumn{1}{|c|}{ Keterangan } & Jumlah \\
\hline & Pegawai Organik & \\
Supervisor/ Penyelia & 5 Orang \\
& Analis Kredit & 1 Orang \\
& Asisten & 20 Orang \\
& Pegawai Outsorch & \\
Direct Sales Dana & 2 Orang \\
& Direct Sales Griya & 2 Orang \\
\hline
\end{tabular}




\begin{tabular}{cc}
\hline Pegawai Dasar & \\
Satpam & 6 Orang \\
Office Boy & 1 Orang \\
Clening Service & 2 Orang \\
Driver & 4 Orang \\
\hline
\end{tabular}

Sumber : Data Karyawan BNI Syariah Palu 2015

\section{A. Operasionalisasi Variabel}

Operasionalisasi variabel dimaksudkan untuk membedakan variabel terikat (dependent variable) dan variabel bebas (independent variable) dari sub variabel serta indikator dari masing-masing variabel penelitian. Variabel yang dianalisis dalam penelitian ini adalah gaya kepemimpinan, motivasi kerja dan budaya organisasi sebagai variabel independen yang di simbolkan dengan variabel $\mathrm{X}$ serta kinerja karyawan sebagai variabel dependen yang disimbolkan dengan variabel $\mathrm{Y}$.

1. Variabel Independen (X)

Variabel independen atau stimulus, preduktor, antecedent, dalam bahasa indonesia sering disebut dengan variabel bebas dengan simbol $X$ yang merupakan variabel yang menjadi sebab perubahan atau timbulnya variabel terikat. Dalam penelitian ini variabel independen (variabel $\mathrm{X}$ ) adalah gaya kepemimpinan, motivasi kerja dan budaya organisasi.

a) Gaya Kepemimpinan $\left(X_{1}\right)$

Dalam penelitian ini variabel independen $\left(X_{1}\right)$ adalah gaya kepemimpinan dengan dimensi variabel tipe otokratis, militeristis, paternalisis, karismatis dan demokratis.

1) Tipe Otokratis

Seorang pemimpin yang otokratis ialah pemimpin yang memiliki kriteria atau ciri sebagai berikut:

a. Menganggap organisasi sebagai pemilik pribadi;

b. Mengidentikkan tujuan pribadi dengan tujuan organisasi;

c. Menganggap bawahan sebagai alat semata-mata;

d. Tidak mau menerima kritik, saran dan pendapat;

e. Terlalu tergantung kepada kekuasaan formalnya;

f. Dalam tindakan penggerakkannya sering mempergunakan pendekatan yang mengandung unsur paksaan dan bersifat menghukum.

2) Tipe Militeristis

Seorang pemimpin yang bertipe militeristis ialah seorang pemimpin yang memiliki sifat-sifat berikut :

a. Dalam menggerakan bawahan sistem perintah yang lebih sering dipergunakan; 
b. Dalam menggerakkan bawahan senang bergantung kepada pangkat dan jabatannya;

c. Senang pada formalitas yang berlebih-lebihan;

d. Menuntut disiplin yang tinggi dan kaku dari bawahan;

e. Sukar menerima kritikan dari bawahannya;

f. Menggemari upacara-upacara untuk berbagai keadaan.

3) Tipe Paternalistis

Seorang pemimpin yang tergolong sebagai pemimpin yang paternalistis ialah seorang yang memiliki ciri sebagai berikut :

a. Menganggap bawahannya sebagai manusia yang tidak dewasa; bersikap terlalu melindungi (overly protective);

b. Jarang memberikan kesempatan kepada bawahannya untuk mengambil keputusan;

c. Jarang memberikan kesempatan kepada bawahannya untuk mengambil inisiatif;

d. Jarang memberikan kesempatan kepada bawahannya untuk mengembangkan daya kreasi dan fantasinya;

a. Sering bersikap maha tahu.

4) Tipe Karismatik

Hingga sekarang ini para ahli belum berhasil menemukan sebabsebab mengapa seseorang pemimpin memiliki karisma. Umumnya diketahui bahwa pemimpin yang demikian mempunyai daya tarik yang amat besar dan karenanya pada umumnya mempunyai pengikut yang jumlahnya yang sangat besar, meskipun para pengikut itu sering pula tidak dapat menjelaskan mengapa mereka menjadi pengikut pemimpin itu, maka sering hanya dikatakan bahwa pemimpin yang demikian diberkahi dengan kekuatan gaib (supra natural powers). Kekayaan, umur, kesehatan, profil tidak dapat dipergunakan sebagai kriteria untuk karisma.

5) Tipe Demokratis

Pengetahuan tentang kepemimpinan telah membuktikan bahwa tipe pemimpin yang demokratislah yang paling tepat untuk organisasi modern. Hal ini terjadi karena tipe kepemimpinan ini memiliki karakteristik sebagai berikut :

a. Dalam proses penggerakan bawahan selalu bertitik tolak dari pendapat bahwa manusia itu adalah makhluk yang termulia di dunia;

b. Selalu berusaha mensinkronisasikan kepentingan dan tujuan organisasi dengan kepentingan dan tujuan pribadi dari pada bawahannya; 
c. Senang menerima saran, pendapat, dan bahkan kritik dari bawahannya;

d. Selalu berusaha mengutamakan kerjasama dan teamwork dalam usaha mencapai tujuan;

e. Ikhlas memberikan kebebasan yang seluas-luasnya kepada bawahannya untuk berbuat kesalahan yang kemudian diperbaiki agar bawahan itu tidak lagi berbuat kesalahan yang sama, tetapi lebih berani untuk berbuat kesalahan yang lain;

f. Selalu berusaha untuk menjadikan bawahannya lebih sukses daripadanya;

g. Berusaha mengembangkan kapasitas diri pribadinya sebagai pemimpin.

2. Motivasi Kerja $\left(\mathrm{X}_{2}\right)$

Manusia memiliki 5 (lima) kebutuhan yang tersusun dalam suatu hiraki dan berawal dari kebutuhan dasar, dimana seseorang akan selalu termotivasi untuk mencakup kebutuhan selanjutnya setelah kebutuhan sebelumnya terpenuhi, ini terjadi secara berurutan (Munandar, 2001), yaitu :

a. Fisiologis : sandang, pangan, papan

b. Rasa aman : keamanan, merdeka, perlindungan

c. Sosial : cinta, afiliasi

d. Harga diri : penghargaan, pengakuan

e. Aktualisasi diri

3. Budaya Organisasi $\left(X_{3}\right)$

Menurut Siagian (2002:201) budaya organisasi mengacu ke suatu sistem makna bersama yang dianut anggota-anggota yang membedakan perusahaan itu terhadap perusahaan lain. Disisi lain, budaya organisasi juga sering diartikan sebagai filosofi dasar yang memberikan arahan bagi karyawan dan konsumen. Berdasarkan berbagai asumsi tersebut, hal penting yang perlu ada dalam definisi budaya organisasi adalah suatu sistem nilai yang dirasakan maknanya oleh seluruh orang dalam perusahaan.

4. Variabel dependen $(\mathrm{Y})$

Variabel dependen atau variabel output, kriteria, konsekuensi, dalam bahasa Indonesia sering disebut dengan variabel terikat dengan simbol $Y$ yang merupakan variabel yang dipengaruhi atau menjadi akibat karena adanya variabel bebas. Dalam penelitian ini yang termasuk variabel terikat (dependen) adalah kinerja karyawan yaitu hasil kerja kualitas dan kuantitas yang dicapai oleh seorang pegawai dalam melaksanakan tugasnya sesuai dengan tanggung jawab yang diberikan kepadanya. 


\section{B. Metode Analisis}

Berdasarkan hipotesis yang telah diajukan, maka pada penelitian ini digunakan regresi linier berganda, yaitu:

$$
\begin{aligned}
& Y=a+b_{1} X_{1}+b_{2} X_{2}+b_{3} X_{3} \\
& \text { Dimana: } \\
& Y=\text { Kinerja Karyawan } \\
& X_{1}=\text { Gaya Kepemimpinan } \\
& X_{2}=\text { Motivasi Kerja } \\
& X_{3}=\text { Budaya Organisasi } \\
& a=\text { Konstanta } \\
& b_{1}-b_{3}=\text { Koefisien Regresi }
\end{aligned}
$$

\section{HASIL DAN PEMBAHASAN}

\section{A. Hasil Pengujian Instrumen Penelitian}

Penelitian ini melibatkan dua macam pengujian yaitu tes kesasihan (test of validity) dan tes keandalan (test of realibility).

\section{Hasil Uji Validitas}

Uji validitas untuk mengukur pernyataan atau pertanyaan yang ada dalam kuesioner. Instrumen yang valid berarti alat ukur yang digunakan untuk mendapatkan data (mengukur) itu valid. Valid berarti instrumen tersebut dapat digunakan untuk mengukur apa yang seharusnya diukur (Sugiyono 2013:173).

\subsection{Gaya Kepemimpinan $\left(\mathrm{X}_{1}\right)$}

Gaya Kepemimpinan merupakan variabel independen kedua yang diteliti dan diwakili dengan 5 (Lima) item pernyataan yang diajukan dalam kuisioner penelitian. Hasil uji validitas dapat dilihat pada tabel dibawah ini :

Tabel 2. Hasil Pengujian Validitas Gaya Kepemimpinan $\left(\mathbf{X}_{1}\right)$

\begin{tabular}{cccc}
\hline Item Pertanyaan & r-hitung & r-kritis & Status \\
\hline Kepentingan Pribadi & 0.553 & 0,3 & Valid \\
Perintah Berlebihan & 0.416 & 0,3 & Valid \\
Mengambil Inisiatif & 0.462 & 0,3 & Valid \\
Sikap Kharismatik & 0.378 & 0,3 & Valid \\
Saran dan Kritik & 0.377 & 0,3 & Valid \\
\hline
\end{tabular}

Sumber : Data Diolah (2015)

\section{Variabel Motivasi Kerja $\left(\mathbf{X}_{\mathbf{2}}\right)$}

Motivasi Kerja merupakan variabel independen kedua yang diteliti dan diwakili dengan 5 (lima) item pernyataan yang diajukan dalam kuisioner 
penelitian. Hasil uji validitas dapat dilihat pada tabel dibawah ini :

Tabel 3. Hasil Pengujian Validitas Motivasi Kerja $\left(\mathrm{X}_{2}\right)$

\begin{tabular}{cccc}
\hline Item Pertanyaan & r-hitung & r-kritis & Status \\
\hline Kebutuhan Ekonomi & 0.535 & 0,3 & Valid \\
Rasa Aman & 0.558 & 0,3 & Valid \\
Hubungan Harmonis & 0.547 & 0,3 & Valid \\
Reward & 0.571 & 0,3 & Valid \\
Kebebasan & 0.388 & 0,3 & Valid \\
\hline
\end{tabular}

Sumber : Data Diolah (2015)

1.2 Variabel Budaya Organisasi $\left(X_{3}\right)$

Budaya Organisasi merupakan variabel independen ketiga yang diteliti dan diwakili dengan 12 (dua belas) item pernyataan yang diajukan dalam kuisioner penelitian. Hasil uji validitas dapat dilihat pada tabel dibawah ini :

Tabel 4. Hasil Pengujian Validitas Budaya Organisasi $\left(\mathrm{X}_{3}\right)$

\begin{tabular}{cccc}
\hline Item Pertanyaan & r-hitung & r-kritis & Status \\
\hline Pionir Perusahaan & 0.575 & 0,3 & Valid \\
Bekerja Baik & 0.596 & 0,3 & Valid \\
Pengambil Keputusan & 0.534 & 0,3 & Valid \\
Kehidupan Pribadi & 0.518 & 0,3 & Valid \\
Berbicara Terbuka & 0.594 & 0,3 & Valid \\
Sikap Optimis & 0.653 & 0,3 & Valid \\
Tepat Waktu & 0.584 & 0,3 & Valid \\
Bekerja Serius & 0.472 & 0,3 & Valid \\
Rasa Curiga & 0.452 & 0,3 & Valid \\
Persaingan Sehat & 0.518 & 0,3 & Valid \\
Karyawan Amanh & 0.600 & 0,3 & Valid \\
Jamaah & 0.672 & 0,3 & Valid \\
\hline
\end{tabular}

Sumber : Data Diolah (2015)

\subsection{Kinerja Karyawan ( $\mathrm{Y}$ )}

Kinerja Karyawan merupakan variabel dependen yang diteliti dan diwakili dengan 16 (enam belas) item pernyataan yang diajukan dalam kuisioner penelitian. Hasil uji validitas dapat dilihat pada tabel dibawah ini :

Tabel 5. Hasil Pengujian Validitas Kinerja Karyawan (Y)

\begin{tabular}{cccc}
\hline Item Pertanyaan & r-hitung & r-kritis & Status \\
\hline Kualitas & 0.460 & 0,3 & Valid \\
Kuantitas & 0.550 & 0,3 & Valid \\
Tepat Waktu & 0.535 & 0,3 & Valid \\
Output & 0.514 & 0,3 & Valid \\
Pengambilan Keputusan & 0.459 & 0,3 & Valid \\
Rasa Percaya Diri & 0.582 & 0,3 & Valid \\
\hline
\end{tabular}


Sumber : Data Dolah (2015)

\section{Uji Reliabilitas}

Setelah instrumen penelitian ini dinyatakan valid, maka selanjutnya dilakukan pengujian reliabilitas instrumen penelitian. Dimana Uji reliabilitas dimaksudkan untuk mengetahui apakah alat pengumpul data pada dasarnya menunjukkan tingkat ketetapan, keakuratan, kestabilan, atau konsistensi alat tersebut dalam mengungkapkan gejala tertentu dari sekelompok individu, walaupun dilakukan terhadap pernyataan-pernyataan yang sudah valid, untuk mengetahui sejauh mana hasil pengukuran tetap konsisten bila dilakukan pengukuran kembali terhadap gejala yang sama. Sugiyono (2006:137), menyatakan instrumen yang valid adalah instrumen yang apabila digunakan beberapa kali untuk mengukur objek yang sama, akan menghasilkan data yang sama. Uji ini dilakukan dengan bantuan computer program SPSS for windows versi 16.0 .

Hasil pengujian reliabilitas dilakukan terhadap item-item pernyataan dari setiap variabel penelitian ini terlihat dalam table berikut :

\section{Tabel 6. Hasil Pengujian Reliabilitas instrument Penelitian}

\begin{tabular}{cccc}
\hline No & Variabel Penelitian & Koefisien Alpha & Keterangan \\
\hline 1 & Gaya Kepemimpinan $\left(\mathrm{X}_{2}\right)$ & 0.679 & Reliabel \\
2 & Motivasi Kerja $\left(\mathrm{X}_{2}\right)$ & 0.729 & Reliabel \\
3 & Budaya Organisasi $\left(\mathrm{X}_{3}\right)$ & 0.846 & Reliabel \\
4 & Kinerja Karyawan $(\mathrm{Y})$ & 0.778 & Reliabel \\
\hline
\end{tabular}

Sumber : Data Diolah (2015)

Hasil diatas menunjukan bahwa sesungguhnya instrument penelitian (kuisioner) yang digunakan dalam penelitian ini reliable atau andal. Hal ini disebabkan karena besarnya nilai Koefisien Alpha Cronbach diatas 0.60 yang berarti memenuhi syarat minimal.

\section{B. Hasil Uji Asumsi Klasik}

Sebelum metode regresi berganda digunakan dalam pengujian hipotesis terlebih dahulu model tersebut akan diuji apakah telah memenuhi asumsi klasik atau tidak. Asumsi klasik dimaksudkan untuk mengetahui apakah koefisien regresi yang didapatkan diterima, serta menghindari kemungkinan adanya pelanggaran asumsi klasik yang merupakan asumsi dasar dalam analisis regresi. Hasil tersebut dapat diharapkan pengambilan keputusan (kesimpulan) hasil uji statistik mendekati nilai estimasi yang sebenarnya. Uji asumsi klasik dalam penelitian ini menggunakan alat bantu SPSS (Statistical Package for Social Sciences) 16.0 for windows.

1. Uji Normalitas

Uji normalitas bertujuan untuk menguji apakah dalam sebuah model regresi, variabel independen, variabel dependen atau keduanya mempunyai distribusi normal. Model regresi yang baik adalah distribusi data normal atau mendekati normal.

Adapun berdasarkan uji normalitas data dengan menggunakan SPSS 16.0 for windows (lampiran IV) diperoleh hasil yang menunjukkan data terdistribusi 
mendekati normal. Berikut grafik histogram yang menunjukkan variabel Kinerja Kerja (Y) mengikuti bentuk distribusi normal, sehingga dapat disimpulkan bahwa distribusi data variabel Kinerja Kerja (Y) memenuhi asumsi normalitas.

Histogram

Dependent Variable: Kinerja Kerja

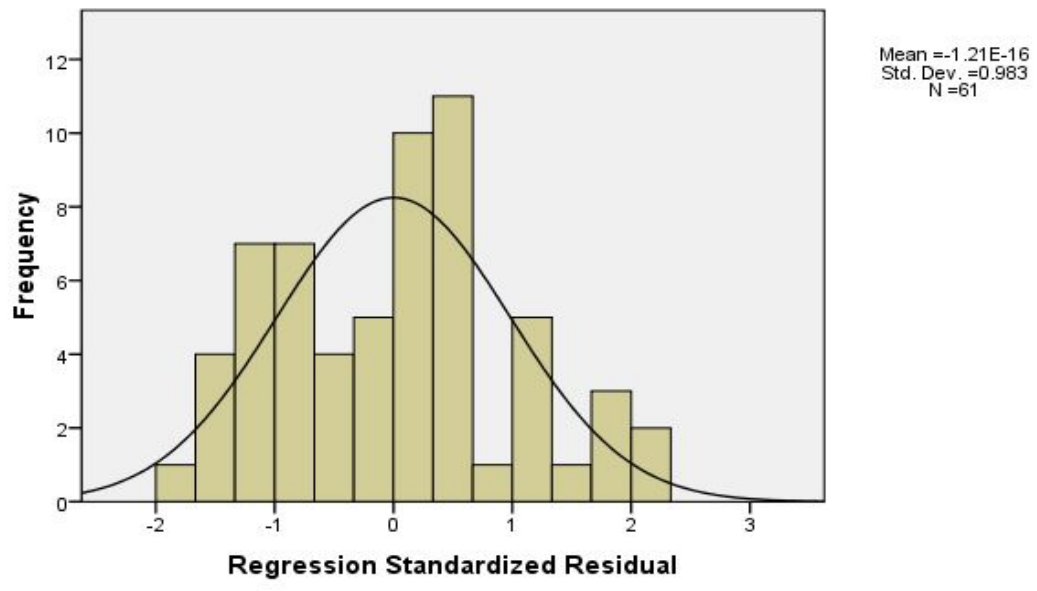

Gambar 1.

Grafik Histogram Uji Normalitas

Selain dengan melihat grafik histogram diatas, normalitas data dapat pula dilakukan dengan melihat probability plot (p-plot), dimana normalitas data dapat dideteksi dengan cara melihat penyebaran data (titik) pada sumbu diagonal dari grafik. Jika data menyebar di sekitar garis diagonal dan mengikuti arah garis diagonal, maka model regresi memenuhi asumsi normalitas dan sebaliknya (Santoso, 2001; 214). Berikut hasil uji normalitas dengan melihat grafik p-plot. 


\section{Normal P-P Plot of Regression Standardized Residual}

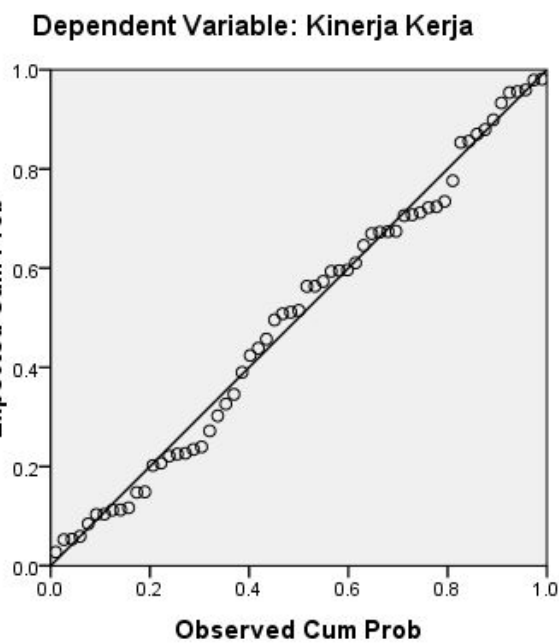

Gambar 2.

Grafik P-P Plot Uji Normalitas

Dari grafik tersebut ditunjukkan bahwa nilai-nilai sebaran data penelitian terletak di sekitar garis diagonal dan mengikuti arah garis diagonal, maka dapat dikatakan bahwa persyaratan normalitas dapat dipenuhi sehingga dapat digunakan untuk metode analisis selanjutnya.

\section{Uji Multikolinearitas}

Untuk mengetahui antar variabel bebas tidak memiliki hubungan linier atau tidak berkolerasi satu sama lain dalam model regresi, maka dilakukan suatu pendeteksian dengan menguji gejala multikolinearitas. Asumsi multikolinearitas menyatakan bahwa variabel independen harus terbebas dari gejala multikolinearitas. Pada penelitian ini digunakan nilai variance inflation factor (VIF) sebagai indikator ada atau tidaknya multikolinearitas diantara variabel bebas. Berdasarkan hasil output dengan bantuan computer program SPSS for windows versi 16.0. (lampiran 4), dapat dilihat hasil uji multikolinearitas untuk masingmasing variabel independen pada tabel dibawah berikut:

Tabel 7. Hasil Pengujian Multikolinearitas

\begin{tabular}{cccc}
\hline No & Variabel Penelitian & Tolerance & VIF \\
\hline 1 & Gaya Kepemimpinan $\left(\mathrm{X}_{1}\right)$ & 0.673 & 1.486 \\
2 & Motivasi Kerja $\left(\mathrm{X}_{2}\right)$ & 0.625 & 1.600 \\
3 & Budaya Organisasi $\left(\mathrm{X}_{3}\right)$ & 0.696 & 1.437 \\
\hline
\end{tabular}

Sumber : Data Diolah (2015) 
Dari nilai tabel diatas dapat dilihat tidak ada variabel independen yang memiliki nilai Tolerance kurang dari 0,10 yang berarti tidak ada korelasi antar variabel independen yang nilainya lebih dari $95 \%$. Hasil perhitungan nilai Variance Inflation Factor (VIF) juga menunjukan hal yang sama, tidak ada satu variabel independen yang memiliki nilai VIF lebih dari 10 maka dapat dikatakan tidak terjadi multikolinearitas (Ghozali, 2006). Dengan demikian dapat disimpulkan bahwa tidak ada multikolineritas antar variabel independen dalam model regresi.

\section{Uji Heteroskedastisitas}

Uji Heteroskedastisitas bertujuan menguji apakah dalam model regresi terjadi ketidaksamaan variance dari residual satu pengamatan ke pengamatan yang lain. Model regresi yang baik adalah Homoskedastisitas atau tidak terjadi Heteroskedastisitas. Deteksi ada tidaknya heteroskedastisitas dapat dilakukan dengan melihat ada tidaknya pola tertentu yang teratur pada grafik Scatterplot. Hasil analisis uji heteroskedastisitas Dari grafik Scatterplot ditunjukkan bahwa nilainilai sebaran data penelitian tersebar secara acak, tidak membentuk suatu pola tertentu yang jelas, tersebar baik diatas maupun dibawah angka nol pada sumbu Y. Hal ini berarti tidak terjadi heterokedastisitas pada model regresi, sehingga model regresi layak digunakan.

\section{Hasil Regresi Linier Berganda}

Penelitian ini mencoba untuk melihat seberapa besar pengaruh Gaya Kepemimpinan, Motivasi Kerja dan Budaya Organisasi terhadap Kinerja Karyawan PT. Bank BNI Syariah Cabang Palu.

Berdasarkan hasil olah data dengan bantuan SPSS 16.0 for Windows, diperoleh hasil analisis regresi berganda pada Tabel berikut.

Tabel 8. Hasil Perhitungan Regresi Linear Berganda

\begin{tabular}{|c|c|c|c|c|c|}
\hline No & Variabel Independen (X) & $\begin{array}{c}\text { Koefisien } \\
\text { Regresi (B) }\end{array}$ & Hasil Üji t & \begin{tabular}{|c|} 
Probabil \\
itas (Sig \\
t)
\end{tabular} & $\begin{array}{c}\text { Koefisien } \\
\text { determinasi } \\
\text { partial }\end{array}$ \\
\hline 1 & Konstanta (a) & 17.431 & 6.293 & .000 & \\
\hline 2 & Gaya Kepemimpinan (X1) & .301 & 2.888 & .006 & .318 \\
\hline 3 & Motivasi Kerja (X2) & .441 & 3.297 & .002 & .376 \\
\hline 4 & Budaya Organisasi (X3) & .206 & 2.873 & .006 & .311 \\
\hline & Variabel Y & $=$ & \multicolumn{3}{|l|}{ Kinerja Karyawan } \\
\hline & Multiple R & $=$ & \multicolumn{3}{|l|}{0.821} \\
\hline & R Square & $=$ & \multicolumn{3}{|l|}{0.674} \\
\hline & Adjusted R Square & $=$ & \multicolumn{3}{|l|}{0.650} \\
\hline & F- hitung & $=$ & \multicolumn{3}{|l|}{71.935} \\
\hline & F-tabel & $=$ & \multicolumn{3}{|l|}{2.816} \\
\hline & t-tabel & $=$ & \multicolumn{3}{|l|}{1.680} \\
\hline
\end{tabular}

Sumber : Data Diolah (2015)

Dari nilai-nilai yang ditunjukkan pada table di atas, diperoleh persamaan model regresi sebagai berikut : 


$$
Y=17,431+0,301 X_{1}+0,441 X_{2}+0,206 X_{3}
$$

Persamaan regresi di atas memberikan gambaran mengenai besarnya pengaruh variabel independen terhadap variabel dependen. Dimana dari koefisien $X_{1}$ (gaya kepemimpinan), $X_{2}$ (motivasi kerja) dan $X_{3}$ (budaya organisasi) yang bertanda positif $(+)$ menunjukkan bahwa terdapat pengaruh yang searah antara variabel independen $\left(X_{1}, X_{2}\right.$ dan $\mathrm{X}_{3}$ ) dengan variabel dependen $(\mathrm{Y})$. Berikut penjelasan hasil perhitungan dari nilai-nilai pada tabel 4.14 di atas.

Nilai $R$ square atau koefisien determinasi diperoleh sebesar 0,674 Nilai tersebut menujukkan besarnya pengaruh variabel independen secara keseluruhan (simultan) terhadap variabel dependen. Sehingga dapat diketahui bahwa secara keseluruhan (simultan) pengaruh variabel independen $\left(X_{1}, X_{2}\right.$ dan $\left.X_{3}\right)$ terhadap variabel dependen $(Y)$ dalam penelitian ini adalah sebesar $67,4 \%$ atau dapat pula diartikan bahwa $67,4 \%$ variasi dari variabel $Y$ dapat dijelaskan oleh variasi dari masing-masing variabel independennya $\left(X_{1}, X_{2}\right.$ dan $X_{3}$ ). Sedangakan sisanya (100 \% - 67,4\%) sebesar 32,6 \% dijelaskan/ merupakan pengaruh dari variabel-variabel lain yang tidak disertakan dalam penelitian ini, diantaranya:
1) kompentensi
2) kompensasi
3) lingkungan kerja
4) fasilitas kerja

\section{PEMBAHASAN}

\section{Pengaruh Gaya Kepemimpinan, Motivasi Kerja dan Budaya Organisasi Terhadap Kinerja Karyawan PT. Bank BNI Syariah Cabang Palu.}

Hipotesis pertama dalam penelitian ini menyatakan bahwa apakah gaya kepemimpinan, motivasi kerja dan budaya organisasi secara simultan berpengaruh signifikan terhadap kinerja karyawan PT. Bank BNI Syariah Cabang Palu. Berdasarkan Hasil uji anova atau $\mathrm{F}$ test pada Tabel 4.12 diperoleh hasil sebesar 71,935 > sebesar 2,816 dengan tingkat probabilitas (signifikan) 0,000 artinya bahwa secara simultan variabel gaya kepemimpinan, motivasi kerja dan budaya kerja berpengaruh signifikan terhadap kinerja karyawan. dengan demikian, hipotesis pertama dalam penelitian ini yang menyatakan bahwa masa kerja, gaya kepemimpinan dan motivasi kerja secara simultan berpengaruh signifikan terhadap kinerja karyawan PT. Bank BNI Syariah Cabang Palu di terima.

Kemudian besarnya pengaruh variabel gaya kepemimpinan, motivasi kerja dan budaya organisasi secara simultan memberikan makna bahwa ada kemampuan yang ditunjukkan dari ketiga variabel independen (bebas) di atas dalam mempengaruhi kinerja karyawan PT. Bank BNI Syariah Cabang Palu dengan nilai sebesar 67,4\%, sedangkan kemampuan lainnya sebesar $32,6 \%$ dipengaruhi oleh variabel lain di luar penelitian ini, yang kemungkinan merupakan dari variabel seperti pendidikan, pelatihan, etos kerja, kecerdasan emosional, kecerdasan spritual, kompensasi, kedisiplinan kerja, komitmen organisasi dan masa kerja. Berdasarkan hasil persamaan regresi yang diperoleh dan telah diuraikan sebelumnya, diketahui nilai koefisien regresi ketiga variabel independen bernilai positif, yang menujukkan bahwa terdapat pengaruh searah antara gaya kepemimpinan, motivasi kerja dan budaya organisasi terhadap kinerja karyawan. Sehingga dari hasil persamaan tersebut dapat 
diketahui jika gaya kepemimpinan, motivasi kerja dan budaya organisasi ditingkatkan maka kinerja karyawan yang dihasilkan dapat meningkat pula.

\section{Pengaruh Gaya Kepemimpinan Secara Terhadap Kinerja Karyawan PT. Bank BNI Syariah Cabang Palu.}

Hipotesis kedua dalam penelitian ini menyatakan bahwa hasil persamaan analisis regresi yang diperoleh dan telah diuraikan sebelumnya, diperoleh nilai nilai thitung sebesar 2,888 > $t_{\text {tabel }}$ sebesar 1,680 dan tingkat signifikansinya lebih kecil dari taraf ketidakpercayaan $5 \%$ $(0,006<0,05)$. Dengan nilai ini memberikan makna bahwa secara parsial variabel gaya kepemimpinan memberikan pengaruh secara positif dan signifikan terhadap kinerja pegawai.

Berdasarkan hasil penelitian koefesien untuk variabel gaya kepemiminan diperoleh nilai koefisien regresi sebesar 0,318. Hal ini berarti apabila gaya kepemimpinan situasional berubah secara positif maka kinerja kerja pegawai akan berubah pula secara positif. Hal tersebut sesuai dengan fenomena yang peneliti amati dilapangan dimana pemimpin dalam kantor ini mampu melakukan diagnosis dengan baik terhadap situasi yang ada, sehingga bawahan patuh dan taat atas perintah dan aturan-aturan yang diberlakukan oleh pemimpin di kantor tersebut.

Pengaruh Motivasi Kerja Terhadap Kinerja Karyawan PT. Bank BNI Syariah Cabang Palu.

Hipotesis ketiga dalam penelitian ini menyatakan bahwa apakah motivasi kerja secara parsial berpengaruh signifikan terhadap kinerja karyawan. Berdasarkan hasil persamaan analisis regresi yang diperoleh dan telah diuraikan sebelumnya, menunjukan bahwa variabel motivasi kerja berpengaruh positif dan signifikan terhadap kinerja karyawan. Hal ini dapat dilihat dari nilai $t_{\text {hitung }}$ sebesar 3,297 $>t_{\text {tabel }}$ sebesar 1,680 dan tingkat signifikansinya lebih kecil dari taraf ketidakpercayaan $5 \%(0,002<0,05)$ sehingga hipotesis ketiga dalam penelitian ini yang menyatakan motivasi kerja secara parsial berpengaruh signifikan terhadap kinerja karyawan PT. Bank BNI Syariah Cabang Palu, diterima. Hal ini menunjukkan bahwa pengaruh motivasi kerja adalah searah dengan kinerja karyawan dengan kata lain motivasi kerja yang baik akan berpengaruh terhadap kinerja karyawan yang baik, demikian sebaliknya bila motivasi kerja buruk maka kinerja karyawan akan rendah/buruk. pengaruh signifikan menunjukkan bahwa motivasi kerja mempunyai peranan yang penting dalam meningkatkan kinerja karyawan.

Berdasarkan hasil penelitian koefesien untuk variabel motivasi kerja adalah sebesar 0,376. Hal ini 'berarti apabila motivasi kerja ditingkatkan maka kinerja kerja karyawan akan meningkat. Jadi dapat disimpulkan bahwa motivasi berpengaruh secara parsial terhadap kinerja karyawan PT. Bank BNI Syariah Cabang Palu. Hal ini menunjukkan bahwa karyawan PT. Bank BNI Syariah Cabang Palu telah berupaya untuk bekerja lebih giat dan menyelesaikan tugas dengan tepat pada waktunya.

Pengaruh Budaya Organisasi Terhadap Kinerja Karyawan PT. Bank BNI Syariah Cabang Palu. Hipotesis keempat dalam penelitian ini menyatakan bahwa apakah budaya organisasi secara parsial berpengaruh signifikan terhadap kinerja karyawan. Berdasarkan hasil persamaan analisis regresi yang diperoleh dan telah diuraikan sebelumnya, menunjukan bahwa variabel motivasi kerja berpengaruh positif dan signifikan terhadap kinerja karyawan. Hal ini dapat dilihat dari nilai $t_{\text {hitung }}$ sebesar 2,873 $>t_{\text {tabel }}$ sebesar 1,680 dan tingkat signifikansinya lebih kecil dari taraf ketidakpercayaan $5 \%(0,006<0,05)$ sehingga hipotesis keempat dalam penelitian ini yang menyatakan budaya kerja secara parsial berpengaruh 
signifikan terhadap kinerja karyawan PT. Bank BNI Syariah Cabang Palu, diterima. Hal ini menunjukkan bahwa pengaruh budaya organisasi adalah searah dengan kinerja karyawan dengan kata lain budaya organisasi yang baik akan berpengaruh terhadap kinerja karyawan yang baik, demikian sebaliknya bila budaya organisasi buruk maka kinerja karyawan akan rendah/buruk. pengaruh signifikan menunjukkan bahwa budaya organisasi mempunyai peranan yang penting dalam meningkatkan kinerja karyawan.

Hasil penelitian ini membuktikan bahwa mempunyai pengaruh posiif dan signifikan terhadap kinerja karyawan, arinya budaya organisasi yang merupakan hasil dari interaksiciriciri kebiasaan yang mempengaruhi kelompok-kelompok orang dalam lingkungan organisasinya, akan membentuk suatu persepsi subyektif kesuluruhan mengenai organisasi dan tujuannya berdasarkan pada faktor-faktor seperti Profesionalisme, jarak dari manajemen, percaya pada rekan sekerja, keteraturan, permusuhan dan integrasi, persepsi keseluruhan ini akan menjadi budaya atau kepribadian organisasi tersebut yang mampu dan mempengaruhi kinerja karyawan serta dampak yang lebih besar pada budaya yang lebih kuat.

Berdasarkan hasil penelitian koefesien untuk variabel budaya kerja adalah sebesar 0,311 . Hal ini 'berarti apabila motivasi kerja ditingkatkan maka kinerja kerja karyawan akan meningkat.

\section{Simpulan}

Setelah dilakukan penelitian pengaruh gaya kepemimpinan, motivasi kerja dan budaya organisasi terhadap kinerja karyawan PT. Bank BNI Syariah Cabang Palu dengan menggunakan analisis regresi linear berganda, maka dapat disimpulkan sebagaiberikut :

1. Hasil pengujian hipotesis dengan menggunakan uji $F$, menyimpulkan bahwa variable gaya kepemimpinan, motivasi kerja dan budaya organisasi secara simultan berpengaruh signifikan terhadap kinerja karyawan PT. Bank BNI Syariah Palu.

2. Variabel gaya kepemimpinan secara parsial berpengaruh positif dan signifikan terhadap kinerja karyawan PT. Bank BNI Syariah Palu.

3. Variabel motivasi kerja secara parsial berpengaruh positif dan signifikan terhadap kinerja karyawan PT. Bank BNI Syariah Palu.

4. Variabel budaya kerja secara parsial berpengaruh positif dan signifikan terhadap kinerja karyawan PT. Bank BNI Syariah Palu.

\section{Saran}

Berdasarkan hasil pembahasan dan kesimpulan yang berkaitan dengan penelitian ini, serta pengalaman dan pengetahuan yang peneliti dapatkan selama proses penelitian, maka direkomendasikan saran-saran sebagai berikut:

1. Bagi PT. Bank BNI Syariah Palu gaya kepemimpinan yang cocok digunakan dalam perusahaan agar kinerja karyawan baik cenderung gaya kepemimpinan yang demokratis.

2. Bagi manajemen PT. Bank BNI Syariah Palu agar dapat memberikan pelatihan yang lebih intensif kepada karyawan agar karyawan lebih mengetahui dan memahami tentang job deskription yang harus mereka kerjakan sehingga tujuan dari perusahaan dapat tercapai dengan maksimal serta kebutuhan akan ekonomi karyawan pun meningkat. 


\section{DAFTAR PUSTAKA}

Abdul Rashid. 2005. "Pengaruh Keadilan Organisasi dan Budaya Organisasi terhadap Kepuasan Gaji, Komitmen Organisasi dan Kinerja", JurnalKeuangan dan Perbankan, Surabaya.

Armstrong, Michael. 1994. Manajemen Sumber Daya Manusia: A Handbook Of Human Resource Management. Jakarta : PT Elex Media Komputindo.

Asep Ishak dan Tanjung Hendri. 2003. Manajemen Motivasi. Jakarta : PT. Gramedia Widiasarana Indonesia.

Atmosoeprapto, Kisdarto. 2001. Produktivitas Aktualisasi Budaya Perusahaan. Jakarta : Alex Media Komputindo.

Bacal R. 2005. Performance Management. Edisi Bahasa Indonesia. Jakarta : PT. Sun.

Bass, B.M dan Avolio, 1990, "The Implications of Transaksional and Transformational", Team and Organization Development, 4, p.231-273

Bass, B.M. (2001), Leadership and performance Beyond Expextations. New York: Free Prees.

Bernardin and Russel, 1993, "Differences In Leadership Behavior And Influence Between Public And Private Organization In Greece," The International Journal of Human ResourcesManagement, 4:4 December.

Chen, Li Yueh, 2004, "Examining The Effect Of Organization Culture And Leadership Behaviors On Organizational Commitment, Job Satisfaction, Adan Job Performance At Small And Middle-Sized Firma Of Taiwan," Journal of American Academy of Business, Sep 2004, 5, $1 / 2,432-438$.

David, Keith. 1985. Fundamental Organizational Behavior. New Delhi: Magrow Hill Company.

Davis, Keith dan Kohn W. Newstrom, Agus Dharma (pent) . 1995. Perilaku Dalam Organisasi. Jakarta : Erlangga.

Dessler. 2000. Manajemen Sumber Daya Manusia. Edisi Bahasa Indonesia Jilid 2. Jakarta: PT. Prenhallindo.

Gibson, J.L., Ivancevich, J.M., dan Donnelly, J.Jr. (1996). Organisasi danManajemen: Perilaku, Sruktur, dan Proses. Edisi Keempat. Jakarta: Penerbit Erlangga.

Handoko, T. Hani, 1998, Manajemen Personal dan Sumber Daya Manusia, BPFE, Yogyakarta.

Heidrajrahcman dan Husnan Suad (2000) "Manajemen Personalia”, Yogyakarta, BPFE.

Hersey, Paul dan Ken Blanchard. 1995. Manajemen Perilaku Organisasi, Pendayagunaan Sumber Daya Manusia, Penerjemah : Agus Dharma. Jakarta : Erlangga.

Hicks, Herbert G, G Ray Gullet. 1995. Organisasi Teori dan Tingkah Laku, terj.G Kartasapoetra \&Ir. A.G. Kartasapoetra. Jakarta: Bumi Aksara.

Irawan, Prasetya. 2000. Manajemen Sumber Daya Manusia. Jakarta : STIA-LAN Press.

Luthans, F. (1998), Organization Behavior. New York: McGraw Hill International. 
Mangkunegara, Anwar Prabu, 2000, Manajemen Sumber Daya Manusia Perusahaan, PT. Remaja Rosdakarya, Bandung.

Manullang, 1996, Pengantar Ekonomi Perusahaan, Edisi Revisi, Cetakan ketujuh belas, Penerbit Liberty.

Martoyo, Susilo, 2007, Manajemen Sumber Daya Manusia, BPFE Yogyakarta.

Mas'ud, Fuad (2002), 40 Mitos Manajemen Sumber Daya Manusia. Semarang: Badan Penerbit Universitas Diponegoro.

Miller. L. M. 1991. Manajemen Era Baru : Beberapa Pandangan Mengenai Budaya Perusahaan Modern. Terjemahan. Jakarta : Erlangga.

Munandar, Ashar Sunyoto, 2001, Psikologi Indutri dan Organisasi, UniversitasIndonesia, Jakarta.

Moeljono, Djokosantoso \& Sudjatmiko, Steve. 2007. Corporate Culture: Challenge toExcellence. Jakarta : PT Elex Media Komputindo Kelompok Gramedia.

Nawawi, Hadari, 2003, Manajemen Sumber Daya Manusia untuk Bisnis yang Kompetetif, Gajah Mada University Press, Yogyakarta.

Prawirosentono, Suyadi. 1999. Kebijakan Kinerja Karyawan, Edisi Ketiga, Yogyakarta : BPFE.

Rivai, Veithzal. 2005. Manajemen Sumber Daya Perusahaan.Jakarta: PT Raja Grafindo Persada.

Santoso Singgih., 2001. Buku Latihan SPSS Statistik Multivariat. Jakarta: Alex Media Komputindo, Gramedia.

Siagian, S.P. 1997. Manajemen Sumber Daya Manusia. Bumi Aksara. Jakarta.

Sugiyono. 2009. Metode Penelitian Administrasi.Penerbit Alfabeta, Bandung.

Sunarsih. 2001. "Kepemimpinan Transformasional Dalam Era Perubahan Organisasi". Jurnal Manajemen dan Bisnis. Vol 5 No. 2. Desember 2001 : 106-116.

Sunindhia dan Ninik Widiyanti, 1998. Manajemen Sumber Daya Manusia. Jakarta : Bumi Aksara.

Tjiptono, F. 2001. Prinsip-Prinsip Total Quality Service. Yogyakarta : Andi.

Umar, Husain, 2003, Metode Riset Bisnis, PT. Gramedia Pustaka Utama, Jakarta.

Wallach, Ellen J. 1983. "Individuals and Organizations : The Culturan Match". Training and Development Journal. Februari. Pp 29-36.

Yukl, Gary A, 1989, "Managerial Leadership: A Review of Theory and Research", Journal of Management, Vol 15, No.2, 251-289.

Yukl, Gary A, (1994), Kepemimpinan Dalam Organisasi, Edisi Bahasa Indonesia : Yusuf Udaaya, Jakarta: Penerbit Prenhallindo 